\title{
Fabry-betegség diagnosztikája modern szívmágnesesrezonancia-technikákkal
}

\author{
Meiszterics Zsófia', Faludi Réka1, Gyimesi Tamás², Kőhalmi Zoltán³, \\ Simor Tamás ${ }^{1}$, Gaszner Balázs ${ }^{1}$
}

${ }^{1}$ Pécsi Tudományegyetem, Klinikai Központ, Szívgyógyászati Klinika, Kardiológia, Pécs
2Pécsi Tudományegyetem, Klinikai Központ, II. sz. Belgyógyászati Klinika és Nephrológiai, Diabetológiai Cent-
rum, Nephrológia, Pécs
${ }^{3}$ MOM, Szt. Magdolna Magánkórház, Budapest

Levelezési cím:

Dr. Gaszner Balázs, Pécsi Tudományegyetem, Klinikai Központ, Szívgyógyászati Klinika, Kardiológia,

7624 Pécs, Ifjúság út 13. E-mail: gaszner.balazs@pte.hu

Bevezetés: A Fabry-betegség férfiaknál 58 év átlagéletkorral járó progresszív, X-kromoszómához kötötten öröklődő tárolási betegség, amelynek kardiális megjelenése hipertrófiás cardiomyopathia fenokópiaként jelentős differenciáldiagnosztikai problémát okoz. Szívmágnesesrezonancia-vizsgálattal (CMR) a betegségre típusos késői típusú kontrasztanyag-halmozás (LGE) előrehaladott szívérintettséget jelez, azonban modern $\mathrm{CMR}$ ( $\mathrm{T}_{1}$-mapping, feature tracking - FT) -technikákkal lehetővé vált a Fabry-betegségre specifikus miokardiális érintettség korai kimutatása.

Esetismertetés: A jelenleg 65 éves férfi betegnél 50 éves korában perzisztáló proteinuria és romló vesefunkciós értékek hátterében genetikai vizsgálatok Fabry-betegséget igazoltak. CMR-vizsgálat jó szisztolés balkamra-funkciót, normál volumetrikus értékeket és balkamra-izomtömeget véleményezett LGE nélkül. 51 éves korától enzimpótló terápiában (ERT) részesül. Típusos anginás panaszok, EKG-eltérések, pozitív koronarográfia miatt CABG-műtét történt. 57 éves korában progrediáló veseelégtelenségre tekintettel sikeres vesetranszplantáción esett át. Echokardiográfiás kontrollok során, klinikai tünetmentesség mellett a balkamra-hipertrófia progrediált. 64 évesen a CMR a betegségre specifikus kardiális eltérések progresszióját mutatta: a kiindulási értékhez képest kétszeresére növekedett balkamra-izomtömeg (148 vs. $328 \mathrm{~g}$ ), bazális inferolaterális midmiokardiális LGE, amelynek megfelelően megrövidült lokális posztkontraszt $T_{1}$ és emelkedett extracelluláris volumenértékek, valamint FT-technikával kóros strainértékek igazolódtak. A kezdeti CMR-felvételek utólagos FT értékelésével a globális és szegmentális strainparaméterek mérsékelt károsodása már akkor megfigyelhető volt.

Következtetések: A modern kardiológiai képalkotó eljárások már a betegség szubklinikus stádiumában is lehetőséget nyújtanak a betegség kardiális manifesztációjának felismerésére, ezzel elősegítve az ERT korai indítását, amivel a szervi érintettségek progressziója lassítható és javítható a betegek túlélése.

Kulcsszavak: Fabry-betegség, kardiovaszkuláris képalkotás, szív-MRI, T1-mapping, feature tracking

A kézirat 2021. 01. 29-én érkezett a szerkesztőségbe, 2020. 02. 25-én került elfogadásra. 
Role of modern cardiac magnetic resonance imaging techniques for the assessment of cardiac involvement in Fabry disease

Introduction: Fabry disease is a rare, progressive, X-linked lysosomal storage disorder with a 58 years (ys) average life expectancy in men. Its cardiac manifestation belongs to the group of hypertrophic cardiomyopathy phenocopies and thus has a differential diagnostic challenge. Disease-specific late gadolinium enhancement (LGE) pattern by cardiac magnetic resonance imaging (CMR) is a sign of advanced disease. Furthermore modern CMR techniques ( $T_{1}$ mapping, feature tracking $\left.-F T\right)$ are suitable for the evaluation of early disease specific myocardial alterations.

Case report: A 65-year-old man with persistent proteinuria and deteriorating renal function was diagnosed with Fabry disease proved by genetic testing at age of 50 ys. Baseline cardiac MRI showed good left ventricular (LV) ejection fraction, normal LV volumetric parameters and normal LV mass without LGE. Enzyme replacement therapy (ERT) was initiated at age of 51 ys. Typical chest pain, ischaemic ECG signs indicated coronary angiography and consequently CABG surgery was performed. Renal failure developed at the age of 57 ys and thus kidney transplantation was carried out successfully. Deteriorating LV hypertrophy was found during the regular echocardiographic check-ups. Cardiac MRI at the age of 64 ys showed all the disease-specific myocardial alterations (doubled LV mass compared to baseline value (148 vs. $328 \mathrm{~g}$ ), basal inferolateral midmyocardial LGE, locally decreased postcontrast T1 mapping and elevated extracellular volume measures and decreased strain values with FT). Postprocessing the baseline MRI images with FT, an early, global and segmental strain reduction was also detectable.

Conclusion: Evaluation of subclinical cardiac involvement with modern imaging techniques is crucial since early ERT may slow down disease progression and can improve life expectancy and survival time.

Keywords: Fabry disease, cardiovascular imaging, cardiac MRI, $T_{1}$ mapping, feature tracking

\section{Bevezetés}

A Fabry-betegség X-kromoszómához kötötten öröklődő lizoszomális tárolási betegség. Az a-galaktozidáz-A ( $\alpha$-gal-A) enzimdefektusa következtében felhalmozódott intracelluláris glikoszfingolipidek több szervrendszer progresszív, strukturális és funkcionális károsodásához és következményes korai halálozáshoz vezetnek (férfiaknál 58 éves átlagéletkor). Elsődlegesen férfiakat érint, de heterozigóta nőkben is megjelenhet, általában enyhébb lefolyással. A kardiális érintettséget a szívizomsejtek fokozott hipertrófiája, valamint apoptotikus, nekrotikus és gyulladásos folyamatok eredményeként létrejött miokardiális fibrózis jellemzi, a vaszkuláris endothelsejtek és az ingerületvezető rendszer fibrózisa mellett (1). Ennek megfelelően szívritmuszavarok (AV-átvezetési zavarok, pitvarfibrilláció, kamrai tachycardia), megtartott ejekciós frakcióval járó szívelégtelenség (heart failure with preserved ejection fraction HFpEF) tünetei, valamint kardiovaszkuláris események idézik elő a korai halálozás jelentős részét (2). A betegség oki terápiája elérhető specifikus intravénás enzimpótlással (enzym replacement therapy - ERT), valamint bizonyos mutációk jelenléte esetén enzimstabilizáló fehérje, a migalasztát orális alkalmazásával. A terápia során a szervi érintettségek progressziója lassítható és javítható a betegek túlélése. Az ERT indikációja a patogén mutációk igazolásán, valamint a célszervkárosodások jelenlétén alapul $(3,4)$. A modern szívmágne- sesrezonancia-technikák (CMR) kiemelkedő szereppel bírnak a strukturális és funkcionális kardiális eltérések korai, akár szubklinikus felismerésében, illetve egyéb hipertrófiás cardiomyopathia (HCM) fenokópiák differenciáldiagnosztikájában.

\section{Esetismertetés}

A jelenleg 65 éves férfi betegnél 50 éves korában perzisztáló proteinuria, romló vesefunkciós értékek (eGFR: $39 \mathrm{ml} /$ perc) miatt nefrológiai kivizsgálás indult. Hasi ultrahang kétoldali veseparenchyma-érintettséget igazolt, vesebiopszia szövettana felvetette Fabry-betegség gyanúját. Enzimaktivitás-mérés során jelentősen csökkent $\alpha$-gal-A aktivitást ( $20 \mathrm{nmol} / \mathrm{pg}-6 \%$ ), valamint a genetikai vizsgálatok Fabry-betegségre patogén mutációt (c.871G>A p.A291T) igazoltak. A többszervi érintettség irányába a neurológiai, bőrgyógyászati, szemészeti, pulmonológiai vizsgálatok nem mutattak a betegségre típusos eltérést. Kardiológiai kivizsgálás során a nyugalmi 12 elvezetéses EKG-n a $V_{5-6}$ elvezetésekben T-inverzió volt látható egyéb ingervezetési, depolarizációs és repolarizációs eltérés nélkül (1. ábra). Echokardiográfia során jó szisztolés balkamra-funkció, normál volumetrikus értékek mellett enyhe diasztolés relaxációs zavar igazolódott, érdemi vitium nélkül. A CMR-vizsgálat normál balkamra-izomtömeg mellett a betegségre 

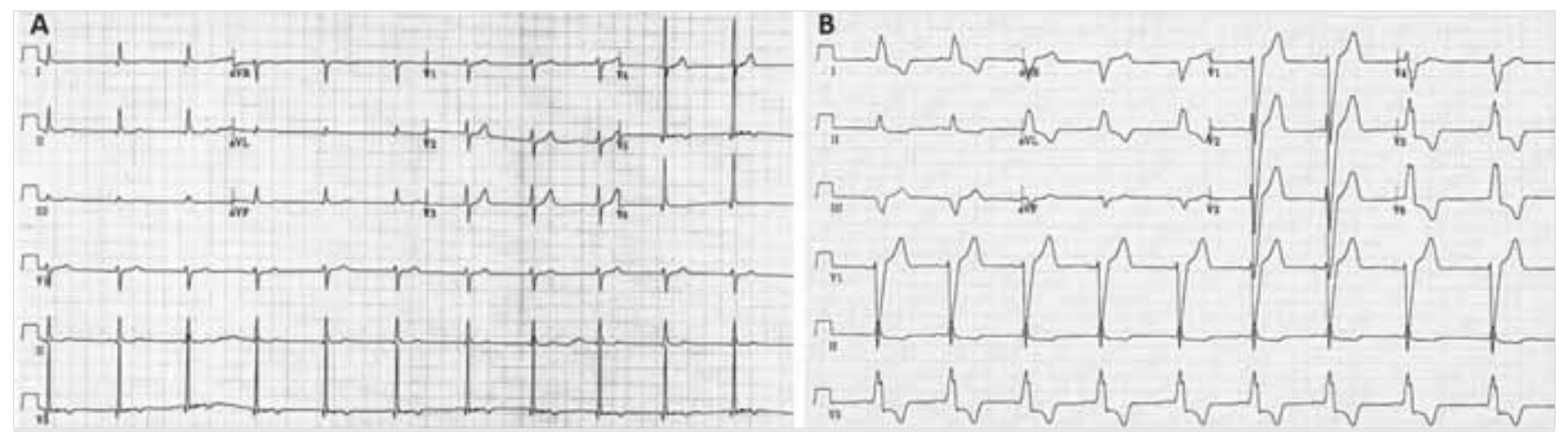

1. ÁBRA. A nyugalmi 12 elvezetéses EKG-n a kiinduláskor (A) érdemi ingerületvezetési, depolarizációs eltérések nem láthatók, $V_{5-6}$ elvezetésekben lapos negatív T-hullámok detektálhatók. Ezzel szemben a 13 évvel később készült EKG-n (B) a kiterjedt kardiális érintettségnek megfelelően, a balkamra-hipertrófia jelei igazolhatók bal Tawara-szár-blokk mellett

specifikus késői típusú kontrasztanyag-halmozást (late gadolinium enhancement - LGE) nem igazolt (2. ábra). A vizsgálatokat összesítve veseérintettségen kívül érdemi célszervkárosodás nem volt detektálható. Mindezekre tekintettel 2007 óta folyamatos ERT-ben részesül.

2008-ban, 53 éves korában típusos anginás panaszok, pozitív noninvazív kardiológiai kivizsgálást követően koronarográfia történt, amely során többszörös, proximális szakaszt is involváló LAD-, valamint RCA-szűkületek igazolódtak. A leírt koszorúér-eltérésekre tekintettel CABG-mütét történt. A korai posztoperatív időszak és a kardiológiai rehabilitáció eseménytelenül zajlott. Rendszeres nefrológiai gondozása során, ERT mellett is progrediáló veseelégtelenség alakult ki, amely miatt 57 éves korában sikeres vesetranszplantáción esett át.

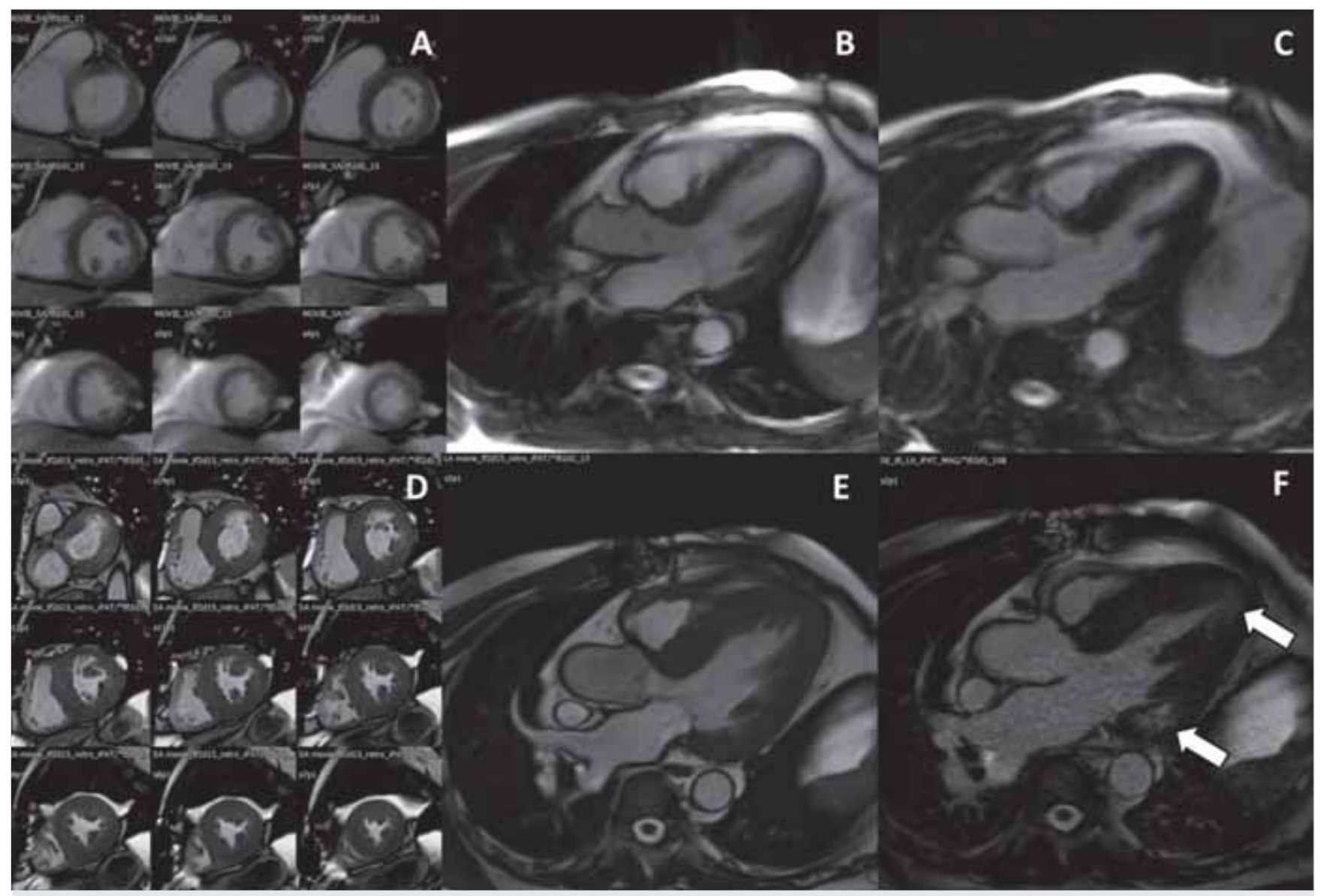

2. ÁBRA. A kiindulási $(A, B, C)$ és a követéses $(D, E, F)$ CMR során készült rövidtengely $(A, D)$ és bal kamrai kiáramlási pálya (LVOT) síkban készült végdiasztolés felvételek ( $\mathrm{B}, \mathrm{E})$, illetve az LVOT-síkban készült $\mathrm{T}_{1}$ súlyozott LGE-felvételek ( $\left.\mathrm{C}, \mathrm{F}\right)$ láthatóak. A CMR-képeket összevetve szembetűnő a balkamra-hipertrófia progressziója $(D, E)$, illetve a bazális inferolaterális és csúcsi midmiokardiális LGE megjelenése ( $F$, nyilak) 
1. TÁBLÁZAT. A kiindulási és utánkövetéses CMR-vizsgálatok során kapott bal kamra és bal pitvar volumetrikus, funkcionális és strainparaméterek változása

\begin{tabular}{|c|c|c|}
\hline CMR-paraméterek & $\begin{array}{c}\text { Kezdeti } \\
\text { CMR }\end{array}$ & $\begin{array}{c}\text { Követéses } \\
\text { CMR }\end{array}$ \\
\hline $\begin{array}{l}\text { Bal kamra végdiasztolés } \\
\text { volumenindex }\left(\mathrm{ml} / \mathrm{m}^{2}\right)\end{array}$ & 79,84 & 75,55 \\
\hline $\begin{array}{l}\text { Bal kamra végszisztolés } \\
\text { volumenindex }\left(\mathrm{ml} / \mathrm{m}^{2}\right)\end{array}$ & 25,25 & 35,03 \\
\hline Bal kamra verővolumen $\left(\mathrm{ml} / \mathrm{m}^{2}\right)$ & 54,58 & 41,52 \\
\hline Bal kamra percvolumen (I/perc) & 5,99 & 4,59 \\
\hline Bal kamrai ejekciós frakció (\%) & 68,36 & 54,24 \\
\hline Bal kamrai izomtömeg (g) & 148,16 & 328,37 \\
\hline LGE & nem & igen \\
\hline Bal kamrai GLS (\%) & $-18,58$ & $-13,11$ \\
\hline Bal kamrai GCS (\%) & $-28,25$ & $-17,27$ \\
\hline $\begin{array}{l}\text { Bal pitvari maximális } \\
\text { volumenindex }\left(\mathrm{ml} / \mathrm{m}^{2}\right)\end{array}$ & 33.64 & 40,83 \\
\hline $\begin{array}{l}\text { Bal pitvari minimális } \\
\text { volumenindex }\left(\mathrm{ml} / \mathrm{m}^{2}\right)\end{array}$ & 13,32 & 19,86 \\
\hline Bal pitvari ejekciós frakció (\%) & 60,39 & 51,35 \\
\hline Bal pitvari rezervoár strain (\%) & 39,90 & 14,11 \\
\hline
\end{tabular}

Éves kontrollok során a beteg kardiálisan tünetmentesnek bizonyult, azonban echokardiográfiás vizsgálatok a balkamra-hipertrófia progresszióját igazolták, amelyet novum EKG-eltérések kísértek (bal Tawaraszár-blokk, emelkedett Sokolow- és Cornell-index) (1. ábra). 64 éves korában, 13 évvel a Fabry-betegség diagnózisát követően készült CMR-vizsgálat (Siemens, Magnetom Avanto Fit, 1,5 T) a betegségre specifikus miokardiális eltérések progresszióját mutatta. A kon- vencionális MR-technikákat alkalmazva, a megtartott szisztolés balkamra-funkció mellett jelentős koncentrikus balkamra-hipertrófiának megfelelö, a kiindulási értékhez képest kétszeresére növekedett balkamra-izomtömeg (148 vs. $328 \mathrm{~g}$ ) igazolódott. A progresszió során a bal pitvari végdiasztolés és végszisztolés volumenek megemelkedtek, valamint a bal pitvari ejekciós frakció a kiindulási értékhez képest csökkent. $A T_{1}$-súlyozott felvételeken megjelent a Fabry-betegségre típusos lokalizációban, a bazális inferolaterális szegmentumban, valamint a csúcsi szegmentumokban midmiokardiálisan a fibrotikus átépülést jelző LGE (2. ábra). A kiindulási és a 13 évvel később készült CMR-vizsgálatok során kapott paramétereket az 1. táblázat mutatja be. Jelenleg már rendelkezésünkre állnak olyan modern, érzékeny CMR-technikák ( $T_{1}$-mapping, extracelluláris volumen - ECV - meghatározás), amelyek a miokardiális szöveti strukturális eltérések korai diagnózisára alkalmasak. Fabry-betegségben a szívizomsejtek kóros lipidakkumulációjának megfelelően a korai akkumulációs, valamint a gyulladásos, hipertrófiás fázisban a natív $T_{1}$ mapping során csökkent $T_{1}$-relaxációs idő detektálható. Ezen CMR-eltérés a balkamra-hipertrófiával járó egyéb kórképek elkülönítésében kiemelt szereppel bír (5). Esetünkben azonban a normáltartomány felső határán lévő natív $T_{1}$-érték igazolódott, amely a betegség késői, fibrotikus stádiumában az intersticiális tér megemelkedése, illetve az ellentétes $\mathrm{T}_{1}$-effektust okozó lipidakkumuláció együttes következménye lehet. Kontrasztanyag adását követően készült $T_{1}$-mapping során a betegségre típusos LGE-nek megfelelő lokalizációkban megrövidült posztkontraszt $T_{1}$-értékeket igazoltunk, valamint az intersticiális fibrózis jelenlétét alátámasztva lokálisan megemelkedett ECV-értékeket kaptunk (3. ábra).

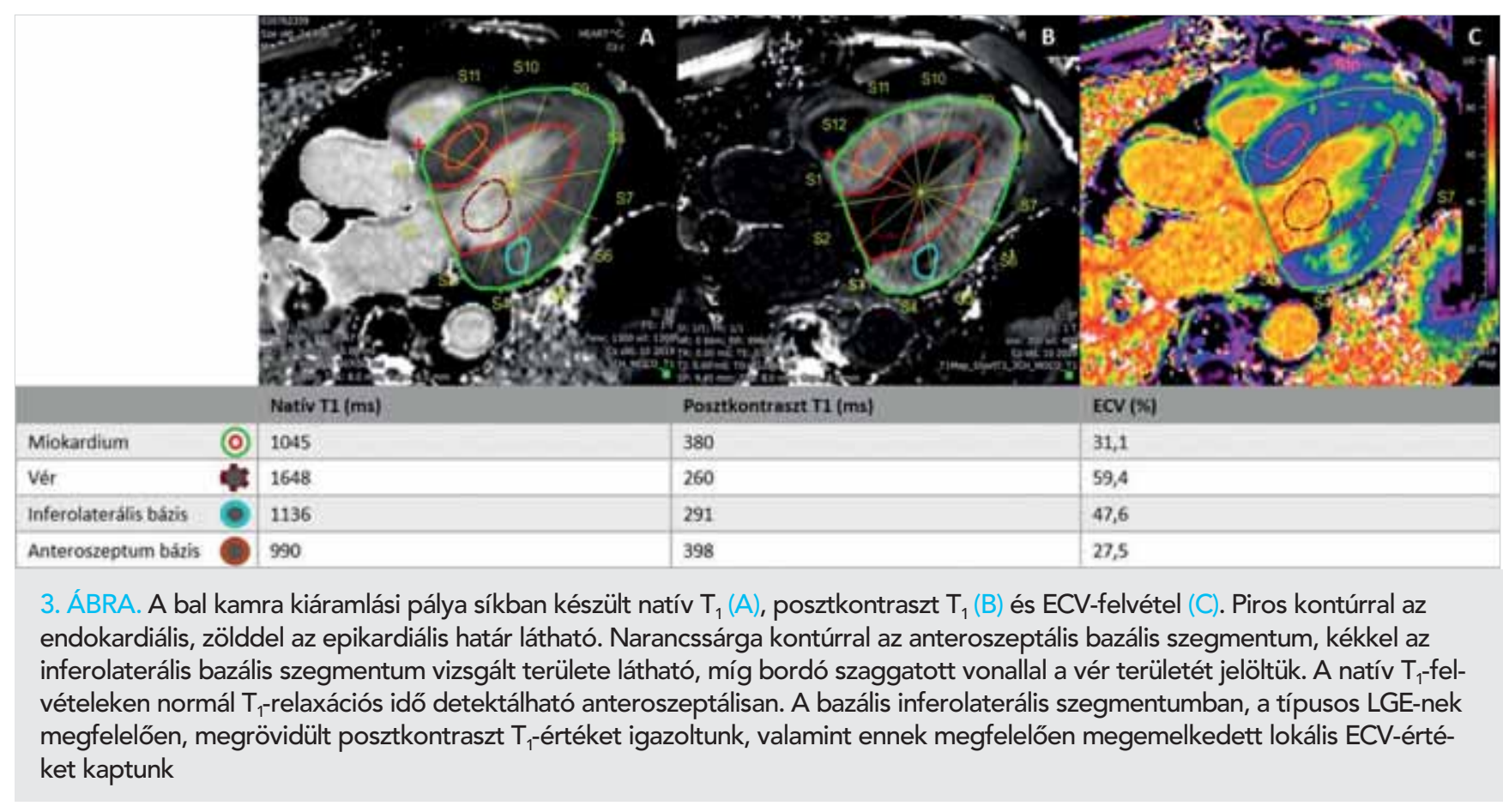




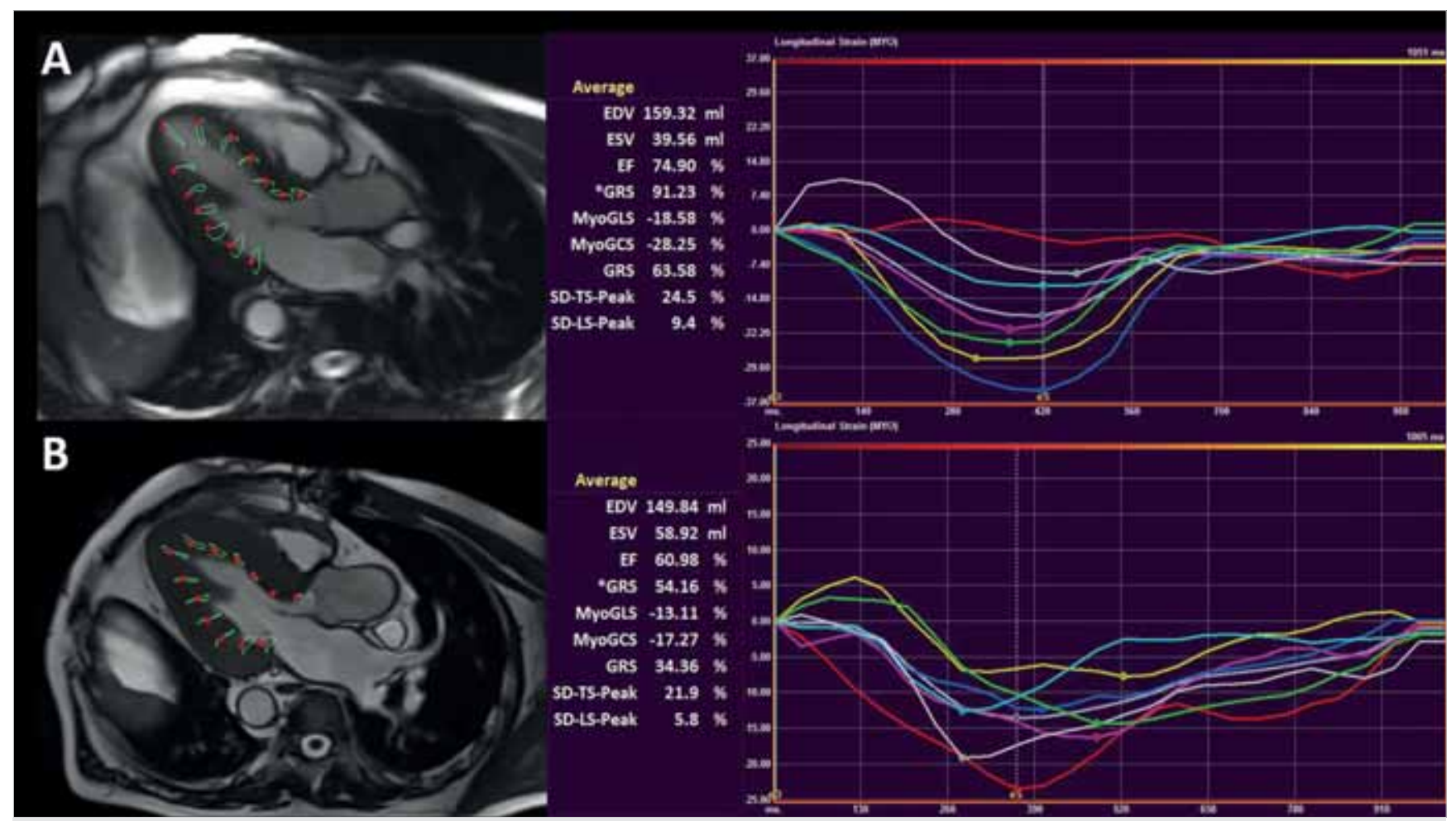

4. ÁBRA. Feature tracking CMR-technika (QStrain 2.0) alkalmazása a bal kamra kiáramlási pálya (LVOT) síkban a kiindulási (A), illetve a követéses (B) felvételeken. A bal kamrai globális strainértékek és az LVOT-síknak megfelelő szegmentális longitudinális straingörbék láthatók

A globális és regionális funkcionális eltérések korai kimutatására alkalmas CMR-technika, a feature tracking (FT) (QStrain 2.0, Medis Suite 3.1) is egyre nagyobb teret nyer a klinikai alkalmazásban. A módszer azonban, mivel nem igényel speciális adatgyűjtést, alkalmas a korábbi CMR-felvételek utólagos elemzésére is. Betegünk esetében, a kiterjedt kardiális érintettségek megjelenésekor jelentősen csökkent globális és károsodott szegmentális longitudinális bal kamrai és bal pitvari FT strainértékeket kaptunk (1. táblázat). A kiindulási CMR-felvételek utólagos FT kiértékelésével a bal kamrai globális longitudinális strain mérsékelt károsodása igazolódott, mindamellett, hogy az akkori konvencionális módszerekkel érdemi morfológiai és/vagy funkcionális eltérés nem volt detektálható (4. ábra) (6). Így a jelenlegi technikai fejlettség segítségével már a kiindulási CMR-felvételeken is kimutathatóvá váltak a korai kardiális szervi érintettség jelei.

\section{Megbeszélés}

A Fabry-betegség kardiális érintettségének kimutatásában, az egyéb noninvazív vizsgálómódszereken túl (EKG, echokardiográfia), a CMR szerepe megkérdőjelezhetetlen. A betegségre jellemző, előrehaladott szívérintettséget jelző morfológiai eltérések (koncentrikus balkamra-hipertrófia, típusos inferobazális midmiokardiális LGE) kimutatására a hagyományos CMR-techni- kák használatosak. Differenciáldiagnosztikai problémát jelenthetnek azonban bizonyos betegségek, amelyek hasonló megjelenésű LGE-t mutathatnak: balkamra-hipertrófiával járó aortastenosis, hipertenzív cardiomyopathia, klorokin indukálta cardiomyopathia. Esetünkben az inferobazális midmiokardiális LGE-mintázat mellett egy szokatlan lokalizációjú, azonban az irodalomban Fabry-betegségben már dokumentált csúcsi fibrózis is kimutatható volt (7).

A jelenleg már elérhető, modern CMR-technikák klinikai alkalmazása lehetőséget nyújt a specifikus miokardiális betegségek korai, gyakran szubklinikus diagnózisára. Az érzékeny mappingtechnikák és feature tracking térhódításával értékes többletinformációt nyerhetünk a korai kardiális manifesztációk meglétéről. A csökkent natív $\mathrm{T}_{1}$-relaxáció a lipidtermészetű anyagok felszaporodását jelző, Fabry-betegségre típusos eltérés, amely már a balkamra-hipertrófia megjelenése előtt is kimutatható (5). A natív $T_{1}$-mapping előnye, hogy kontrasztanyag adása nélkül kapunk információt a szöveti szintü miokardiális eltérésekről, így akár kialakult veseelégtelenség esetén is alkalmazható és jelentős segítséget nyújthat egyéb kórképek elkülönítésében (HCM, amyloidosis). Fabry-betegségre típusos miokardiális kórlefolyás során három stádium különíthető el, amelyek kifejezésre kerülnek a CMR-képalkotás során: az első korai akkumulációs, valamint a második gyulladásos, hipertrófiás fázis alacsony natív szeptális $T_{1}$-értékekkel jellemezhetők, azonban a harmadik késői, fibrotikus fá- 
zis során „pszeudonormalizált” $T_{1}$-értékek detektálhatók kiterjedt LGE-vel, jelentős balkamra-hipertrófiával. Betegünk követéses vizsgálata már ezen késői, kiterjedt fibrózissal járó stádiumban készült, ennek megfelelően natív $T_{1}$-értéke nem tért el a normál tartománytól. Amennyiben kontrasztanyag adása nem kontraindikált, úgy a natív és a posztkontraszt $T_{1}$-térképezés segítségével az extracelluláris tér százalékos aránya is kiszámítható, amely ugyancsak segíti a különböző etiológiájú balkamra-hipertrófiák differenciáldiagnosztikáját. Fabry-betegség esetén a miokardiális fibrózis mintázatának megfelelöen lokális ECV-növekedés volt igazolható, míg a myocardium globális ECV-értéke a normáltartományban maradt, amely a szfingolipid-felszaporodás intracelluláris jellegével magyarázható $(5,8)$.

A CMR-alapú strainanalízis (FT) segítségével a korai, akár szubklinikus globális és regionális miokardiális funkcionális eltérések is felismerhetővé válnak, ezáltal nemcsak a célszervkárosodások diagnosztikájában jelent egy érzékeny technikát, hanem a kardiális manifesztáció progressziójának megítélésében is új lehetőséget teremt. Betegünknél a kezdeti CMR-felvételek utólagos FT elemzésével kimutathatóvá vált a strainparaméterek szubklinikus károsodása, normál bal kamrai volumetrikus és funkcionális értékek mellett. A bal pitvari volumenindex növekedése és strainértékek károsodása szintén jelezheti a korai kardiális érintettséget, ezáltal mérésük fontos additív információt nyújthat a célszervkárosodások diagnózisában (9).

A betegek életminőségének és életkilátásainak javítására, valamint a súlyos klinikai tünetek megelőzésének érdekében - a tüneti kezelés mellett - esszenciális az oki terápia, az ERT- vagy chaperonterápia minél koraibb megkezdése. A szöveti károsodások kialakulása elött indított ERT esetén várható a legjobb terápiás válasz. Elörehaladott szervi érintettségek esetén oki terápiával csak a betegség progressziójának lassítása érhető el. Azon betegeknél, ahol az ERT megkezdésekor miokardiális fibrózis nem volt igazolható, a bal kamra relaxációs funkció javulása, valamint a bal kamrai izomtömeg csökkenése várható. Azonban ERT indításakor már jelenlévő vesefunkciós károsodás, proteinuria és/ vagy miokardiális fibrózis esetén a szervi érintettségek progressziója figyelhető meg ERT alkalmazása ellenére is (10). A már kialakult progresszív kardiális érintettség esetén a HFpEF ajánlásoknak megfelelő terápia felépítése és a ritmuszavarok megelőzése és/vagy kezelése is alapvető fontosságú.

\section{Következtetések}

A modern CMR-technikák ( $T_{1}$ mapping, ECV-meghatározás, feature tracking) a Fabry-betegség szubklinikus stádiumában is lehetóséget nyújtanak a kardiális manifesztációk felismerésére, ezzel elősegítve az optimális oki terápia (ERT-, chaperonterápia) indítását, aminek korai alkalmazásával a szervi érintettségek progressziója lassítható és javítható a betegek túlélése.

\section{Nyilatkozat}

A szerzők kijelentik, hogy az esetismertetés megírásával kapcsolatban nem áll fenn velük szemben pénzügyi vagy egyéb lényeges összeütközés, öszszeférhetetlenségi ok, amely befolyásolhatja a közleményben bemutatott eredményeket, az abból levont következtetéseket vagy azok értelmezését.

\section{Irodalom}

1. Linhart A, Germain DP, Olivotto I, et al. An expert consensus document on the management of cardiovascular manifestations of Fabry disease. European Journal of Heart Failure 2020; 22: 1076-1096 https://doi.org/10.1002/ejhf.1960ejhf1960

2. Waldek S, Patel MR, Banikazemi M, Lemay R, Lee P. Life expectancy and cause of death in males and females with Fabry disease: findings from the Fabry Registry. Genetics in medicine : official journal of the American College of Medical Genetics 2009; 11(11): 7906. https://doi.org/10.1097/GIM.0b013e3181bb05bb

3. Constantin T, Székely A, Ponyi A, Gulácsy V, Ambrus C, Kádár K, et al. [Fabry-betegség - terápiás útmutató]. Orvosi hetilap 2010; 151(31): 1243-51. https://doi.org/10.1556/OH.2010.28796

4. Ortiz A, Germain DP, Desnick RJ, Politei J, Mauer M, Burlina A, et al. Fabry disease revisited: Management and treatment recommendations for adult patients. Molecular genetics and metabolism 2018; 123(4): 416-27. https://doi.org/10.1016/j.ymgme.2018.02.014. 5. Nordin S, Kozor R, Medina-Menacho K, et al. Proposed Stages of Myocardial Phenotype Development in Fabry Disease. JACC Cardiovascular Imaging 2019; 8(Pt 2): 1673-1683.

https://doi.org/10.1016/j.jcmg.2018.03.020

6. Williams LK, Forero JF, Popovic ZB, et al. Patterns of CMR measured longitudinal strain and its association with late gadolinium enhancement in patients with cardiac amyloidosis and its mimics. Journal of Cardiovascular Magnetic Resonance 2017; 19(1): 61

https://doi.org/10.1186/s12968-017-0376-0

7. Deva DP, Hanneman K, Li Q, Ng MY, Wasim S, Morel C, et al. Cardiovascular magnetic resonance demonstration of the spectrum of morphological phenotypes and patterns of myocardial scarring in Anderson-Fabry disease. Journal of cardiovascular magnetic resonance: official journal of the Society for Cardiovascular Magnetic Resonance 2016; 18: 14. https://doi.org/10.1186/s12968-016-0233-6 8. Haaf P, Garg P, Messroghli DR, Broadbent DA, Greenwood JP, Plein S. Cardiac T1 Mapping and Extracellular Volume (ECV) in clinical practice: a comprehensive review. Journal of cardiovascular magnetic resonance: official journal of the Society for Cardiovascular Magnetic Resonance 2016; 18(1): 89

https://doi.org/10.1186/s12968-016-0308-4

9. Boyd AC, Lo Q, Devine K, Tchan MC, Sillence DO, Sadick N, et al. Left atrial enlargement and reduced atrial compliance occurs early in Fabry cardiomyopathy. Journal of the American Society of Echocardiography: official publication of the American Society of Echocardiography 2013; 26(12): 1415-23.

https://doi.org/10.1016/j.echo.2013.08.024

10. Arends M, Biegstraaten M, Hughes DA, Mehta A, Elliott PM, Oder D, et al. Retrospective study of long-term outcomes of enzyme replacement therapy in Fabry disease: Analysis of prognostic factors. PloS one 2017; 12(8): e0182379.

https://doi.org/10.1371/journal.pone.0182379 